\title{
Extent of the Target Cost Application in Commercial Banks in Aqaba Special Economic Zone
}

\author{
Dr. Farouq Al Azzam \\ Dean of Aqaba University College (AUC) \\ Al-Balqa' Applied University (BAU), Jordan
}

Received: Dec. 20, 2012

Accepted: January 13, 2013 Published: January 16, 2013

doi:10.5296/jmr.v5i1.2919

URL: http://dx.doi.org/10.5296/jmr.v5i1.2919

\begin{abstract}
This study investigates the method of target cost and the difficulties that commercial banks face in Aqaba Special Economic Zone. The study depends on a questionnaire to collect the primary data and analyze them statistically to come out with the results. The results show that banks in ASEZ do analyze the customers' needs and market with some concentration on service design but the banks lack to the strategy of team work. The sub-constituents were compatible with the dimensions that they are related to with some exceptions in which services price is not determined by the customers' capability. In addition, there are no continuous studies which identify competitors' new services. Furthermore, the number of employees involved in determining the appropriate form of service is not sufficient. The study revealed that there are no obstacles which hinder application of this approach except the internal organizational clash of departments target and the management doesn't take into consideration the employees' suggestions in the following modern ways in cost management.

The study recommended that banks in ASEZ should consider the customers' abilities in determining services price and conduct continuous studies to identify competitor's new services. In addition, the banks should embrace enough number of employees to determine the appropriate form of service to act in the spirit of teamwork. The management should make use of employees' opinions and experiences and aware the employees of their important role in taking decisions in cost reduction. The management should also lessen the internal organizational conflicts resulting from department objectives clashes through cooperation in tasks execution. The management should consider the employees' suggestion in pursuing and applying modern approaches which help in cost management.
\end{abstract}

Keywords: Target cost, Banks, Aqaba, Jordan 


\section{Introduction}

The interest of the establishment in the past regarding costs was focused on calculating objective cost of different costs, to use in some administrative decisions relating some matters such as pricing, performance assessment, supervision and planning, the used methods and techniques in the costing process lacked precision, and did not find adequate attention from management for several reasons, the most important reason was the unwillingness of the administration. But the role of cost calculating has recent developed due to the increased need for some accurate information, both in its financial and non-financial sides and for the various activities and operations of the business, for several reasons, the most important ones are developments and increased competition.

The continued increase in the intensity of competition, led to the search for effective and sophisticated methods to manage and reduce costs without affecting the quality of the product, or the wishes of the customers. Information technology helped this development. This has led to the emergence of so-called target cost method. It requires several components and principles, to apply this method accurately, this method integrates with many things that belong to management costs.

Targeted cost method is Associated form the beginning with the industrial sector, but it has been used in all sectors, such as the service sector and the banking sector which is facing severe competition in terms of quality, price and time, so it resort to the application of this method so that it can face the competition and earn satisfied customers.

\section{The problem of the study}

The study problem revolves around the banking sector and ways to improve the observed cost, because of the need of advanced methods and costs systems for emerging challenges,, i.e., that the problem of the study is that the used costs methods in Aqaba banks are not clear, especially regarding target cost method, is this method is being applied and to any extent, and if the ingredients to apply this method is available, and what difficulties face the banks in the application of this method.

\section{The importance of the study}

The importance of the study came for the importance of the banking sector role in development, intense competition facing this sector, and because of the privacy of the Aqaba Special economic zone, and its importance also comes from the importance of target cost method as a means of relatively modern methods to reduce costs, and also the importance of the study comes form the few studies which examines the application of this method in the banking sector in general and particulary in Aqab.

\section{Study objectives}

The study aims to:

1. identify the extent to which the banks in Aqaba Special economic zone analyses customer needs. 


\section{Macrothink}

Journal of Management Research

ISSN 1941-899X

2013, Vol. 5, No. 1

2. identify the extent to which the banks in the region of Aqaba Special economic zone analyses the market.

3. identify the extent to which the banks in Aqaba Special economic zone leans on value engineering.

4. identify the extent to which the banks in Aqaba Special economic zone in efforts for continuous improvements to reduce costs.

5. identify whether banks in Aqaba Special economic zone faces any major or basic difficulties in target cost method application .

\section{The study hypotheses}

This study tests the following hypotheses:

1. bank in Aqaba Special economic zone analysis customers needs.

2. banks in Aqaba Special economic zone analysis the market.

3. banks in Aqaba Special economic zone focuses on service design.

4. banks in Aqaba Special economic zone have the teamwork spirit.

5. banks in Aqaba Special economic zone works for continuous improvements to reduce costs.

\section{Methodology of the study}

The study used the analytical descriptive approach, where primary data was collection from the study community and analyzed statistically to reach conclusions about the study areas. The questionnaire is the primary data collection tool that is designed to measure the existing realities in the banks of the study community.

\section{Community study}

The study community consists of the 19 commercial banks operating in the Aqaba Special economic zone authority.

\section{Study tool}

questionnaire have been distributed -57 questionnaire- to various banks, 3 questionnaires for each bank, 54 have been restored, 3 questionnaires were excluded because of a significant shortfall. The questionnaires method based on closed questions, with (strongly agree, agree, neutral, disagree, strongly disagree) answers available. And the previous answers have been weighting by degrees $(5,4,3,2,1)$ respectively.

\section{Previous studies}

\section{* Al Jazeerah Study (2009):}

The study aimed to determine to who extent does the target cost participate in raising the decisions efficiency in lighting prices devices industry in Syria. The study found that the gap 
between the current cost of the product and the targeted cost is distributed to the cost components that are possible to be reduced in order to reach the target cost.

*Almatarneh Study (2008):

The study aimed to identify areas were target cost method is used in Jordanian industrial corporations and identify the ingredients availability for applying this way, and the presence difficulties of impeding its implementation.

The study found that there are some ingredients to apply this method such as providing a market that is characterized by fierce competition, the company determines the period needed for the product to develop, and quick providing of raw materials.

The study also found that there are some obstacles to the application of this method such as fluctuations in raw material prices, fear of new methods adoption by the Department, and the high costs of the application.

* Zanini Study (2007):

The study aimed to identify the Croatian hotel extent of applying the target cost method as well as the application of activity-based costing system, and their role in determining the quality cost .

The study found that there is an application to a target cost side by side with activity-based costing system, and have an important role in quality cost, leading to more effective implementation of the hotels.

* Ibusuki and Kaminiski Study (2007):

The study aimed to explore the role of value engineering and target cost in cost managing in one car companies, it was found that it led to a reduction in the cost of products in the company while maintaining the appropriatness of these products to the wishes of the customers.

* Alrihawi Study (2006):

The study aimed to discuss ways of calculating costs of products including target cost method. And study the influence of these ways in decision-making, specially in pricing and production decisions.

The study found that there is a possiblity to reach specific target cost through product design and in a way that provides high quality. The study confirmed the role of cost data in product pricing through understanding the causes of costs in the various functions of the value chain.

* Marliyn Study (2005):

The study aimed to clarify the content of the application of target cost management through practical examples in some industries, and highlighted the challenges of implementation and practical importance. 
The study found that the targeted cost system is more focused on time than the traditional methods, the time is required to fetch all costs through a series of support to acceptable levels. And also reached that the implementation of this method requires comprehensive coordination between financial specialists and accounting specialist.

* Borgernas Study (2003):

The study aimed to identify the the application extent of the Swedish industrial companies to target cost method. The study found that $16.5 \%$ of these companies apply this method and most of these companies are discribed as massive ones, and found that the main reason for not applying this method in other companies is the lack of information.

* Carr et al Study. (2002):

The aim of this study is to identify the steps which "levies" company took in order to face the competition that led to low sales, the study found that the company has been using the method of analysis based on value chain and this is what has led to success in raising market share and compete successfully.

\section{Target cost method}

Traditional systems based on using cost method (cost plus ...), where this traditional method based on estimating the costs of producing of the product first and then add the required marginal profit from the product to cost as a basis to get the sale price in the market, and if the market does not accept this price and cannot sell using it, at that point they start thinking in a way or means to cut costs.

The idea of target cost method based on access for target profit depending on the price at which the client can pay through reaching a cost that acheives this profit i.e at the beginning of the target price is identified and target profit and then the target costing is identifyed (allowable cost), then it will be reached through cutting costs through several methods and procedures used across the various stages of the life of the product.

\section{Application of target cost method}

certain principles, requirements and steps must be available as cost mothod depend on it, in order to determined target costing form one side and reaching it form the other hand, some of them are cost determined the price, by the following equation: target cost $=$ product competitive price in market - target profit, and also analyzing customer needs, where customer orientation and needs in terms of quality, price and time to determine which product must be produced, its characteristics and the specifications need by the customer, one of these principles is to consentrate on the design because this process effect all the stages of the product manufacturing and the life cycle of this product. One of the principles is to use the value chain in order to contain the process of reducing the costs of manufactring in all departments and sections. And also must provide an integrated team of various disciplines, job functions and departments, to reach the target cost of production .Finally the application of target cost method requires continuous improvement with the aim of reducing costs, improving quality, and improving production process, after the actual start of production 
operations. The process of reducing costs here must be continuous and simple, and by the time it becomes relatively large.

\section{Commercial Banks}

Banks have a global and remarkable place in our current time and in all commercial, economic and financial activities in the countries, the global economic development has led to a focus on banking in its various forms.

Banks strive to complete its work and various functions efficiently and effectively, in view of the multiplicity and diversity of functions, various tasks are being performed through several sections. Bank division depends on the nature of the activities or services that the bank provides. All these factors are taken into account to determine the working sections and how to distribute it, and then determine the amount of costs the Bank have to bear to achieve the financial objective which is represented by an acceptable profit for the Bank management. Until the bank reachs the acceptable profit it must follow a successful cost system that accurately measure the various financial burdens related to services and periodic financial burdens associated with the organizational structure of the bank in order to be able to reduce costs and thus increase profits or maintaining profits under competition.

\section{The description of personal and functional factors of respondents}

Table number (1) shows a description of the functional and personal factors of respondents working in banks, as follow

- $\quad$ Educations: through the study of education level, it was found that $64.5 \%$ of the sample of the study are bacholer holders, $22.6 \%$ diploma, and $12.9 \%$ of the sample of obtaining general secondary

- $\quad$ Scientific specialization of the sample: $45.1 \%$ were found to be allocated from the specimen banking and financial Sciences, and 25.8\% business management, $22.6 \%$ accounting, and 6.5\% from other disciplines.

- Years of experience: where 35.5\% of the sample have 15 years and more of experience, and $22.6 \%$ of those between $1-5$ years experiences, and the same percentage of them ranging services between $6-10$, and $19.4 \%$ whose experience ranging between $11-15$ years.

- $\quad$ Job level: the table shows that $29 \%$ of the sample were section heads, and $25.8 \%$ who hold Deputy Director, and the same percentage were of the staff, $19.4 \%$ were managers.

\section{Tool Persistence}

* Tool Persistence has been tested by cronbach's alpha, looking at table number (2) we can see the following

1. alpha value for the dimension related to analysing the needs of customers 0.86

2. alpha value for the dimension related to analysing the needs of market 0.91 . 


\section{Macrothink}

Journal of Management Research

ISSN 1941-899X

2013, Vol. 5, No. 1

3. alpha value for the dimension related to service design 0.74

4. alpha value for the dimension related to having the teamwork spirit 0.90

5. alpha value for the dimension related to continuous improvements to reduce costs 0.91

6. alpha value for all paragraphs combined 0.87

All these values are greater than 0.60 which means that this study tool is persistence

\section{Testing Hypothesis}

First Hypothesis: the commercial banks in the Aqaba Special economic zone analyses customer needs.

Table 3 shows that, with the exception of paragraph No. 5, all the paragraphs got arithmetic mean greater than 3.00 , and got observation level less than 0.05 , i.e statistically acceptable.

Paragraph (3) which measure banks identify the services desired by customers, ranked first and with 4.35 arithmetic mean.

Paragraph No. 5, which measure the banks dependance on the customers ability to define services prices, although it has got arithmetic mean greater than 3.00 but the observation level was greater than 0.05 , i.e. was not statistically significance.

Arithmetic mean for all Paragraphs combined was average 4.05 which is greater than 3.00, and 0.00 total observation level, which means that there is statistical significance to accept the first hypothesis, i.e that the banks in Aqaba Special economic zone does analyse customer needs.

The Second Hypothesis: Commercial banks in the region of Aqaba Special economic zone do market analysis

Table 4 shows that, with the exception of paragraph (10), all the paragraphs got arithmetic mean greater than 3.00 , and got observation level less than 0.05 , i.e statistically acceptable.

Paragraph number (8) which measure the banks ongoing studies to identify new services of the competitors, ranked first and with 4.03 arithmetic mean.

Paragraph number (10) which measure the banks undertake continuous studies to know the abilities of new competitor accessing, although it has got arithmetic mean greater than 3.00 but the observation level was greater than 0.05 , i.e. not-statistically acceptable.

Arithmetic mean for all paragraphs combined was 3.83 greater than 3.00, 0.00 an observation level, which means that there is a statistical significance to accept the second hypothesis, i.e. that banks in Aqaba Special economic zone do market analysis.

The Third Hypothesis: Banks in the economic obstacle by focusing on service design. 


\section{Macrothink}

Table No. (5) indicated that, with the exception of paragraph (13), all paragraphs have got arithmetic mean greater than 3.00 , and got observation level less than 0.05 , i.e statistically acceptable.

Paragraph number (15) which measure the banks determining the shape and characteristics of service from the begining and on an a previosuly identified basis, ranked first and with 3.81arithmetic mean.

Paragraph number (13) which measure the banks involving a large number of staff to determine the form of the appropriate service, although it has got arithmetic mean greater than 3.00 but the observation level was greater than 0.05 , i.e. not statistically acceptable. This means that the banks do not involve staff in identifying appropriate service form.

All the paragraphs combined got 3.60 arithmetic mean greater than 3.00 , total 0.00 observation level, i.e it is statistically significance to accept the third hypothesis, that banks in Aqaba Special economic zone focusing on service design.

The Fourth Hypothesis: Banks in Aqaba Special economic zone work with team spirit.

Table 6 shows that, with the exception of paragraph (19), all other paragraphs have got arithmetic mean less than 3.00, i.e.:

1. Department doesn't encourage the experiences exchange between the different sections through decentralization.

2. Bank management does not benefit from the experiences and views of staff on the services provided.

3. Department doen't notify the staff of the importance of their role in the decision to reduce cost.

Paragraph number (19) which measure the banks developing relations of employees in various sections, got arithmetic mean greater than 3.00 and observation level less than 0.05 , that is statistically significance.

The arithmetic mean for all paragraphs combined was 3.08 which is greater than 3.00 , but the observation level is greater than 0.05, i.e. that there is no statistical significance to accept the fourth hypothesis, which means that the banks in Aqaba Special economic zone does not work with team spirit.

The Fifth Hypothesis: Banks in the region of Aqaba Special economic zone make efforts for continuous improvements to reduce costs.

Table 7 shows that, with the exception of paragraph (23), (24), all other paragraphs have got arithmetic mean greater than 3.00 and observation level less than 0.05 , it is statistically acceptable.

Paragraph number (26) which measure the banks interest to identify the causes of the appropriate cost, ranked first and with 4.29arithmetic mean. 
Paragraph number (23) and (24) which measure the banks interest in any deductions for costs no matter if the size is small, and the extent to which banks compares the performance of services with the performance of services at other banks, the arithmetic mean for each one was greater than 3.00 but the observation level of each one is greater than 0.05 . they are not statistically significant.

The arithmetic mean for all paragraphs combined was 3.57 and is greater than 3.00 , the observation level was 0.002 , i.e there is statistical significance for accepting the fifth hypothesis, which means that banks in Aqaba Special economic zone make efforts for continuous improvements to reduce costs.

\section{Results}

The study reached the following results:

1. banks in Aqaba Special economic zone analyses customer needs. But don't rely on the ability of customers to determine prices for services.

2. banks in the region of Aqaba Special economic zone analyses the market, but they don't perform ongoing studies to identify new services to competitors.

3. banks in the Aqaba Special economic zone focus on service design. But it does not involve a sufficient number of staff to determine the appropriate service form.

4. banks in Aqaba Special economic zone don't work with team spirit. They don't encourages the department to exchange experiences between different sections through decentralization, and do not benefit from the experiences and views of staff on the services provided, staff does not feel the importance of their role in the decision to reduce cost. But it develops the relations between different working sections.

5. There is an internal organizational struggle through the conflicts of sections objectives, and the management doesn't hear the Bank staff proposals in using a modern ways to manage costs.

6. except as mentioned in the previous paragraph, banks in the Aqaba Special economic zone is do not face any other difficulties that is impeding the application of target cost method, where the fundamentals for applying it is available.

\section{Recommendations}

Based on the results of the study, the study recommends:

1. the study recommends that banks in the special economic zone of Aqaba depends on the ability of customers to determine prices for services.

2. the study recommends that banks in the the special economic zone of Aqaba do more studies for identify new services of the competitors.

3. banks in Aqaba Special economic zone must involve a sufficient number of staff to determine the appropriate service form. 
4. the need for banks in Aqaba Special economic zone to work with team spirit, So the Administration encourages the exchange of experience between different sections through decentralization, and benefit from the experiences and views of staff on the services provided, and therefore the Department notified the staff the importance of their role in the decision to reduce cost.

5. banks need to reduce internal organizational conflict resulting from conflicting goals of sections and through collaborating the implementation of tasks.

6. the bank's management need to hear the staff proposals in modern ways to manage costs and collaborate with them and taking their views into considration.

\section{References}

Abu hashish, K. (2005). Cost Accounting. Amman, Jordan.Wael publishing.

Abu Nassar, M. (2010). Management Accounting. Amman,Jordan.Wael Publishin.

Almatarneh, G. (2008). Entrance requirements and constraints apply at target cost Jordanian industrial companies. Journal of Economics and legal, 24(2), 277-305.

Borgenas, H., \& Fridh, G. (2003). The Use Of Target Costing In Swedish Manufacturing Firms.

Carr, L. P., Lawler, W.C., \& Shank, J. K. (2002). Reconfiguring The Value Chain: Levis Personal Pair. Journal of Cost Management, 9-17.

Choe, J .(2002) . The organizational learning effects of management accounting information under advanced manufacturing technology. European Journal of Information Systems, 11(2), 142-150. http://dx.doi.org/10.1057/palgrave/ejis/3000424

Faker, N., \& Alglilati, M.( 2006). Cost Accounting (3).Damascus, Syria.Damascus University publications.

Horngren, C., Foster, G., \& Datar. (2010). Cost Accounting: Managerial Emphasis. New jersey: Prentice - Hall International.

Ibusuki, U., \& Kaminiski, P. (2007). Product Development Process With Focus on Value Engineering and Target-Costing: Case Study in an Automotive Company. International Journal of Production Economics, 105(2), 8-93. http://dx.doi.org/10.1016/j.ijpe.2005.08.009

Jarerah, T. (2009). Proposal form to use target system cost for upgrading pricing decisions. Administrative Journal, 31(116), 81-106.

Kahalah, J., \& Hanan, R. (2004). Management Accounting. Amman, Jordan. International scientific House of culture publishing and distribution.

Marilyn, M., Lawrence, P., Joe, T., \& Matthew, W. (2005). Managerial implications of target costing, 15(49), 79-79.

Retrieved Month Day, Year, from Name of database. 
Retrieved Month Day, Year, from Name of database.

Retrieved Month Day, Year, from Name of database.

Retrieved Month Day, Year, from Name of database.

Retrieved Month Day, Year, from Name of database.

Retrieved Month Day, Year, from Name of database.

Rihawi, M. (2006). Impact of cost data and ways to reduce pricing decisions. Administrative Journal, 104, 78-79.

Rugby, Mohammed. (2004). Management Accounting. Amman, Jordan.Wael Publishing.

Yilmaz1, R., \& Gökhan, B. (2010). Target costing as a strategic cost management tool for success of balanced scorecard system. Business Review, 9, 39-54.

Zanini, Tatiana. (2007). Monitoring of Quality Costs in the Croatian Hotel Industry. Organization, 4, 218-228.

Table 1. Frequency and the percentage of the personal variables of the sample:

\begin{tabular}{|l|l|l|l|}
\hline Factor & & Frequency & Percentage \% \\
\hline \multirow{5}{*}{ Specialization } & business administration & 4 & 25.8 \\
\cline { 2 - 4 } & Financial & 14 & 45.1 \\
\cline { 2 - 4 } & Accounting & 7 & 22.6 \\
\cline { 2 - 4 } & others & 2 & 6.5 \\
\hline \multirow{5}{*}{ Educations } & secondary & 4 & 12.9 \\
\cline { 2 - 4 } & Diploma & 7 & 22.6 \\
\cline { 2 - 4 } & Bacholer holders & 20 & 64.5 \\
\cline { 2 - 4 } & Master degree & --- & --- \\
\hline \multirow{5}{*}{ Job level of experience } & $5-1$ & 7 & 22.6 \\
\cline { 2 - 4 } & $6-10$ & 7 & 22.6 \\
\cline { 2 - 4 } & $11-15$ & 6 & 19.4 \\
\cline { 2 - 4 } & More than 15 & 11 & 35.5 \\
\hline & administrator & 6 & 19.4 \\
\cline { 2 - 4 } & Deputy Director & 8 & 25.8 \\
\cline { 2 - 4 } & Head of section & 9 & 29.0 \\
\cline { 2 - 4 } & Employee & 8 & 25.8 \\
\hline
\end{tabular}


Table 2. Cronbach's alpha values for the study dimensions

\begin{tabular}{|l|l|}
\hline Dimension & Cronbach's Alpha \\
\hline Analysis the needs of clients & 0.86 \\
\hline market analysis & 0.91 \\
\hline Preliminary design for service & 0.74 \\
\hline Teamwork spirit & 0.90 \\
\hline Kaizen method for continuous improvement & 0.91 \\
\hline Total & 0.87 \\
\hline
\end{tabular}

Table 3. Arithmetic mean, standard deviation, the value of $t$ and observation level to analyses the customer needs

\begin{tabular}{|l|l|l|l|l|l|}
\hline No. & Paragraphs & $\begin{array}{l}\text { arithmetic } \\
\text { mean }\end{array}$ & $\begin{array}{l}\text { standard } \\
\text { deviation }\end{array}$ & t value & $\begin{array}{l}\text { observation } \\
\text { level }\end{array}$ \\
\hline 1 & $\begin{array}{l}\text { the Bank responds to the services that } \\
\text { customers wishes to have }\end{array}$ & 4.226 & 0.805 & 8.483 & 0,000 \\
\hline 2. & $\begin{array}{l}\text { the Bank identify the client's ability to pay to } \\
\text { determined the services to provide }\end{array}$ & 4.194 & 0.654 & 10.158 & 0.000 \\
\hline 3. & $\begin{array}{l}\text { The bank identify the services desired by the } \\
\text { clients }\end{array}$ & 4.355 & 0.709 & 10.634 & 0,000 \\
\hline 4. & $\begin{array}{l}\text { Bank continuously identify the services } \\
\text { desired by customers }\end{array}$ & 4.194 & 0.980 & 6.778 & 0.000 \\
\hline 5. & $\begin{array}{l}\text { services prices is determined based on } \\
\text { customer estimated ability }\end{array}$ & & 1.323 & 1.668 & 0.106 \\
\hline 6. & Total & 4.058 & 0.689 & 8.546 & 0.00 \\
\hline
\end{tabular}


Table 4. Arithmetic mean, standard deviation, the value of $t$ and observation level to analyses the market needs

\begin{tabular}{|l|l|l|l|l|l|}
\hline No. & Paragraphs & $\begin{array}{l}\text { arithmetic } \\
\text { mean }\end{array}$ & $\begin{array}{l}\text { standard } \\
\text { deviation }\end{array}$ & $\begin{array}{l}\mathrm{t} \\
\text { value }\end{array}$ & $\begin{array}{l}\text { observation } \\
\text { level }\end{array}$ \\
\hline 6 & $\begin{array}{l}\text { the Bank study competitors prices to determine } \\
\text { the prices for its services }\end{array}$ & 3.936 & 1,340 & 3.887 & 0.001 \\
\hline 7 & $\begin{array}{l}\text { the Bank study and follow-up the factors } \\
\text { affecting the banking sector }\end{array}$ & 3.742 & 1.632 & 2.531 & 0.017 \\
\hline 8 & $\begin{array}{l}\text { the Bank do a continuing studies to identify } \\
\text { new services provided by the competitors }\end{array}$ & 4.032 & 0.912 & 6.300 & 0,000 \\
\hline 9 & $\begin{array}{l}\text { the Bank do a continuing studies to identify the } \\
\text { quality of the services provided by competitors }\end{array}$ & 3.839 & 1.157 & 4.034 & 0,000 \\
\hline 10 & $\begin{array}{l}\text { the Bank do continuing studies to determine } \\
\text { the possibility of new competitior accessing }\end{array}$ & 3.452 & 1.457 & 1.726 & 0.095 \\
\hline 11 & Bank do studies of for competing Services price & 3.645 & 1.305 & 2.752 & 0.010 \\
\hline & Total & 3.774 & 1.101 & 3.915 & 0,000 \\
\hline
\end{tabular}

Table 5. Arithmetic mean, standard deviation, the value of $t$ and observation level to focus on service design

\begin{tabular}{|l|l|l|l|l|l|}
\hline No. & Paragraphs & $\begin{array}{l}\text { arithmetic } \\
\text { mean }\end{array}$ & $\begin{array}{l}\text { standard } \\
\text { deviation }\end{array}$ & $\begin{array}{l}\mathrm{t} \\
\text { value }\end{array}$ & $\begin{array}{l}\text { observation } \\
\text { level }\end{array}$ \\
\hline 12 & $\begin{array}{l}\text { Bank is interested in identifying the stages of } \\
\text { service between sections }\end{array}$ & 3.774 & 1.203 & 0.001 \\
\hline 13 & $\begin{array}{l}\text { Bank involves a large number of staff to } \\
\text { determine the appropriate service form }\end{array}$ & 3.194 & 1.078 & 1.000 & 0.325 \\
\hline 14 & $\begin{array}{l}\text { there are specialists to determine time needed to } \\
\text { service }\end{array}$ & 3.581 & 0.848 & 3.815 & 0.001 \\
\hline 15 & $\begin{array}{l}\text { the Bank identify the form and characteristics } \\
\text { of service from the begining and on specific } \\
\text { grounds }\end{array}$ & 3.831 & 0.921 & 4.683 & 0,000 \\
\hline 16 & Bank cares about the quality of services provided & 3.677 & 1.447 & 2.607 & 0.014 \\
\hline & Total & 3.600 & 0.790 & 4.229 & 0,000 \\
\hline
\end{tabular}




\section{Macrothink}

Journal of Management Research

ISSN 1941-899X

2013, Vol. 5, No. 1

Table 6. Arithmetic mean, standard deviation, the value of $\mathrm{t}$ and observation level to work with team spirit

\begin{tabular}{|l|l|l|l|l|l|}
\hline No. & Paragraphs & $\begin{array}{l}\text { arithmetic } \\
\text { mean }\end{array}$ & $\begin{array}{l}\text { standard } \\
\text { deviation }\end{array}$ & $\begin{array}{l}\text { t } \\
\text { value }\end{array}$ & $\begin{array}{l}\text { observation } \\
\text { level }\end{array}$ \\
\hline 17 & $\begin{array}{l}\text { Department encourages the experiences exchange } \\
\text { between the different sections through } \\
\text { decentralization. }\end{array}$ & 2.774 & 1.055 & $1.191-$ & 0.243 \\
\hline 18 & $\begin{array}{l}\text { Bank management benefit from the experiences } \\
\text { and views of staff on the services provided. }\end{array}$ & 2.936 & 1.289 & $0.279-$ & 0.782 \\
\hline 19 & $\begin{array}{l}\text { he banks developing relations of employees in } \\
\text { various sections }\end{array}$ & 3.839 & 1.293 & 3.610 & 0.001 \\
\hline 20 & $\begin{array}{l}\text { Department notify the staff of the importance of } \\
\text { their role in the decision to reduce cost. }\end{array}$ & 2.774 & 1.175 & $1.070-$ & 0.293 \\
\hline & Total & 3.081 & 1.067 & 0.421 & 0.677 \\
\hline
\end{tabular}

Table 7. Arithmetic mean, standard deviation, the value of $t$ and observation level to focus on service design

\begin{tabular}{|l|l|l|l|l|l|}
\hline No. & Paragraphs & $\begin{array}{l}\text { arithmetic } \\
\text { mean }\end{array}$ & $\begin{array}{l}\text { standard } \\
\text { deviation }\end{array}$ & t value & $\begin{array}{l}\text { observation } \\
\text { level }\end{array}$ \\
\hline 21 & $\begin{array}{l}\text { banks studye the ways of cost reduction in other } \\
\text { competitive banks }\end{array}$ & 3.419 & 0.720 & 3.243 & 0.003 \\
\hline 22 & $\begin{array}{l}\text { Bank work to reduce some of the costs of } \\
\text { services without affecting the essential quality }\end{array}$ & 3.516 & 0.962 & 2.988 & 0.008 \\
\hline 23 & $\begin{array}{l}\text { bank cares about any reductions of costs no } \\
\text { matter what size it is }\end{array}$ & 3.419 & 1.432 & 1.630 & 0.114 \\
\hline 24 & $\begin{array}{l}\text { the Bank compares the performance of services } \\
\text { with the performance of services at other banks }\end{array}$ & 3.290 & 1.321 & 1.223 & 0.231 \\
\hline 25 & $\begin{array}{l}\text { Bank strengthens oversight role on the uneven } \\
\text { sections }\end{array}$ & 4.226 & 0.845 & 8.077 & 0.000 \\
\hline 26 & $\begin{array}{l}\text { the banks interest to identify the causes of the } \\
\text { appropriate cost }\end{array}$ & 4.290 & 0.693 & 10.374 & 0.000 \\
\hline & Total & 3.574 & 0.938 & 3.409 & 0.002 \\
\hline
\end{tabular}

